\title{
Making Place for the iConsumer in Consumer Law
}

\author{
Natali Helberger
}

Received: 29 October 2008 / Accepted: 6 November 2008 /

Published online: 5 December 2008

(C) The Author(s) 2008. This article is published with open access at Springerlink.com

This special JCP issue deals with the iConsumer and their search for rules that would accommodate their specific concerns and interests. For a long time, consumers of audiovisual services, music, e-Books, and computer games have led a shadow existence as 'eyeballs', 'couch potatoes', or 'nerds'. The times, however, seem to be over. The digital consumer (or iConsumer) is high on the political agenda. In the wake of the Lisbon agenda, iConsumers of today are subject to an entire battery of measures that are meant to enhance consumers' confidence in 'the largest information economy of the world' and their active participation in making Europe's ambitious visions work.

A critical obstacle for Europe's information economy are the concerns of iConsumers when purchasing digital information products and services. Over the past few years, it has become apparent that there are many discrepancies between the rights and interests of consumers and the way digital content is marketed. Some of the conflicts arising have even made their way to the courts. In a number of recent cases in France, Belgium, and Germany, ${ }^{1}$ consumers complained about overly restrictive contracts and technological measures that would prevent them from private copying and playing legitimately purchased CDs on their computers or car radios. The Norwegian consumer ombudsman has filed a

\footnotetext{
${ }^{1}$ Tribunal de grande instance (T.G.I.) Nanterre, decision of 2 September 2003 (Francoise M.), online available at: http://www.legalis.net; Tribunal de grande instance (T.G.I.) Paris, decision of 10 January 2005 (Christophe R.), online available at: http://www.legalis.net; Tribunal de grande instance (T.G.I.) Paris, decision of 30 April 2004 (Stéphane P.), online available at: http://www.legalis.net; Court de Cassation (CC) Paris, decision of 28 February 2006 (Stéphane P.), online available at: http://www.legalis.net; Court d'appel (CA) Paris, decision of 4 April 2007, (Stéphane P.), online available at: http://www.legalis.net; Tribunal de première instance (T.P.I.) Brussels, decision of 25 May 2004, Rôle de Référes 2004, 46. German Federal Supreme Court, decision of 15. November 2007 (Central Federal German Consumer Association v Premiere Fernsehen GmbH \& Co. KG), in: Entertainment Law Review 2006-6, p. 39.
}

N. Helberger $(\bowtie)$

Institute for Information Law (IViR), University of Amsterdam, Rokin 84, 1012 KX Amsterdam, The Netherlands

e-mail: helberger@ivir.nl 
complaint with the Norwegian Market Authority against iTunes' contract terms and the fact that songs purchased via iTunes can in principle only be played with Apple's iPod. ${ }^{2}$ Sony, too, made headlines with its attempts to spy on the usage behaviour of customers who bought its CDs, and some of these CDs have been found to interfere with, or even harm consumer's property (Mulligan and Perzanowski 2007, p. 1157). Consumers fear for their privacy when finding themselves targeted with increasing frequency by 'behavioural advertising'. Disabled users are disgruntled because restrictive content protection technologies on e-Books can disable programmes that would read these books aloud to them. Moreover, consumers are frequently confronted with situations in which common forms of using informational content in the analogue age (sharing a $\mathrm{CD}$ with friends, reading a book aloud, making a collage from different photos, time-shifting a video, making back-ups of a film) are no longer permitted and sometimes even criminalized in the digital age. At the same time, users are often not very well informed about potential restrictions in the number of copies they are allowed to make of a $\mathrm{CD}$, or on which devices such a CD would actually play (INDICARE 2006). The list of incidents and concerns could be continued further (Helberger et al. 2004, pp. 20-32; Samuelson and Schultz 2007, pp. 46-59). It is obvious that this situation is neither in the interest of consumers nor in the interest of industry.

Many of the concerns of iConsumers are the result of tensions between their wish to make the best of digital technologies and the interest of the content industry to exercise some form of control over the use and distribution of digital content in order to maintain a viable business model. Both interests are in principle legitimate and fair. The challenge is to reconcile the conflicting interests and to find a balanced solution. Traditionally, the interests of the content industry and authors to control the dissemination and use of protected music, films, games, etc. are protected by copyright law. Having said this, in past consultations and discussions, it soon became apparent that there is little place for the consumer in copyright law (Helberger and Hugenholtz 2007, pp. 1073-1078). Copyright law has been designed in the first place to regulate the relationship between rightholders and intermediaries, e.g., music publishers. This may also explain why copyright law lacks a coherent concept of 'the consumer' (Cohen 2005, pp. 372; Liu 2003, pp. 398, 401-420). The prevalent characterization of 'the consumer' in copyright literature is still the economic representation of an individual whose main interest is maximum consumption at the cheapest possible price, as opposed to the 'user' or 'individual' whose interests are predominantly creative and non-economic in nature (Liu 2003, pp. 402-406). The reality of many iConsumers lies between both of these extremes. Arguably, also the scope, objectives, and structure of existing copyright laws not only in Europe but also in the USA are not to particularly well adapt to address the concerns of consumers. Copyright law has traditionally focused on the author of creative works, defining his rights and limitations of his privileges. Concrete rights of consumers had no place in this structure (Helberger and Hugenholtz 2007, pp. 1073-1078). Finally, many of the concerns of the iConsumer are not so much, or not only, the result of the existence of exclusive rights that copyright law bestows upon rightholders, but they rather result from the way protected content is marketed and sold to consumers.

The concerns of the digital consumer and the present uncertain legal situation has led to various calls for more clearly defined digital consumer rights. Consumer organizations, academics, and digital rights groups have presented proposals and guidelines for consumer

\footnotetext{
${ }^{2}$ Heise online, "Norwegen lässt bei iTunes nicht locker", 30 september 2008, online available at: http:// www.heise.de/newsticker/Norwegen-laesst-bei-iTunes-nicht-locker-/meldung/116732
} 
rights' catalogues. ${ }^{3}$ Under the German EU presidency, the German Federal Ministry for Food, Agriculture and Consumer Protection adopted a Charter on Consumer Sovereignty in the Digital World. ${ }^{4}$ The charter emphasizes that 'the increasing importance of digital media calls for a comprehensive consumer policy concept and the formulation of clear consumer rights regarding the use of digital services'. The charter lists a number of rights that digital users should be entitled to: security and reliability of information and communication technology, protection of personal data, access to digital media and information, legitimacy of the way how copyrights are exercised and technical content protection and management technologies are implemented, transparency, inclusion, and interoperability, to name but a few. In response, the European Parliament has called on the European Commission to present a European charter of users' rights (European Parliament 2007, recital 25). This charter would need to clarify the rights and obligations of information society players, notably users' rights relating to digital content, interoperability and the rights of disabled persons. The parliament also called on the Commission to establish 'basic users' freedoms and rights'. The concerns of consumers of digital products and services also figured prominently in the ongoing review of the consumer law acquis (Commission 2007a, b, p. 6; Kroes 2008), ${ }^{5}$ the recent proposal for a Directive on consumer rights, ${ }^{6}$ the review of European communications law (European Parliament 2008) and copyright law (CEC 2008), or the Services Directive, ${ }^{7}$ which is now in the process of implementation.

One essential question when discussing how to improve the legal position of iConsumers is where and in which form to accommodate digital consumer rights. The opinions are divided between two major approaches. One approach suggests adapting copyright law so that it can address properly the concerns of iConsumers. Proponents of this approach point towards the need of striking the right balance between the exploitation interests of the content industry and the rights and freedoms of consumers of copyright protected material, something that could be best done in copyright law. In his contribution to this JCP issue, Professor Jens Schovsbo explores this route and takes it one step further by making concrete suggestions as to how to integrate consumers' rights into the existing structures of copyright law.

A viable alternative turns towards consumer law. Consumer law has traditionally been the place to set basic rules for the commercial interaction between 'persons acting as consumer in the marketplace and their counterparts, the businesses' (Wilhelmsson 1998,

\footnotetext{
${ }^{3}$ BEUC_European Consumers' Organisation: Declaration of Consumers' Digital Rights. Online available at: http://www.beuc.eu/Content/Default.asp?PageID=825; Digital Copyright Canada: Petition for Users' Rights. Online available at: http:/www.digital-copyright.ca/petition/petition en.pdf; DigitalConsumer.org: The Consumer Technology Bill of Rights. Online available at: http://www.digitalconsumer.org/; Electronic Frontier Foundation: The Customer Is Always Wrong: A User's Guide to DRM in Online Music. Online available at: http://www.eff.org/pages/customer-always-wrong-users-guide-drm-online-music; Public Knowledge: What every citizen should know about DRM. Online available at: http://www.publicknowledge.org/pdf/ citizens_guide_to_drm.pdf.

${ }^{4}$ Online available at: http://www.bmelv.de/nn_757130/SharedDocs/downloads/_EN/03-ConsumerProtection/ CharterDig.html.

${ }^{5}$ The responses to the public consultation on the green paper are available at http://ec.europa.eu/consumers/ cons_int/safe_shop/acquis/acquis_working_doc.pdf.

${ }^{6}$ European Commission, Proposal for a Directive of the European Parliament and of the Council on consumer rights, Brussels, 8.10.2008, $\operatorname{COM}(2008) 614 / 3$.

${ }^{7}$ Directive 2006/123/EC of the European Parliament and of the Council of 12 December 2006 on services in the internal market ('Services Directive'), OJ L 376/36 (27.12.2006).
} 
p. 46). As such, consumer law addresses problems that arise in the commercial dealings between consumers and the digital industry. The idea of protecting the interests of digital consumers with the tools of consumer law is not entirely alien to information law either. ECommerce law ${ }^{8}$, for example, has developed specific rules on advertising and the formation of contracts in the case of so-called information society services, such as video on demand services and music download sites. Telecommunications law, and here in particular the Universal Service Directive, ${ }^{9}$ mandates interoperability for certain parts of consumer equipment, takes into account the interests of disabled consumers, and stipulates rules regarding the lawfulness of contracts between telecommunications service providers and consumers. One objective of these rules is that consumers can access telecommunications services under fair, non-discriminatory and affordable conditions. Broadcasting law ${ }^{10}$ protects consumers from excessive or misleading advertising in television broadcasting. In other words, protecting the iConsumer with consumer protection rules already has a tradition in certain fields of information law.

Having said this, the consumer law approach has also met with considerable distrust and criticism, notably from the proponents of a copyright law approach. Some of this criticism is directed at the concept of 'the consumer'. It has been frequently argued that the traditional concept of the consumer is too narrow, self-centred and profit-oriented, leaving no room to reflect the far more diverse, non-economic, creative, and democratic interests of the user as citizen. Other criticism targets scope and structure of consumer law: that it would protect exclusively the economic interests of consumers and that it was vague and that its remedies were not sufficient to accommodate the needs of the iConsumer (Benkler 2000, p. 564; Elkin-Koren 2007, p. 1126-1129).

Three other papers in this issue have taken up the challenge. They investigate whether existing European consumer law offers room to accommodate the interests of the iConsumer. In the first of these papers, Dr. Lucie Guibault scrutinizes a number of European consumer protection directives, and here in particular their information requirements and the provisions on unfair contractual terms. Which information are undertakings obliged to give consumers under European law, and do these requirements meet the specific information needs ${ }^{11}$ of iConsumers? And to what extent does European contract law protect consumer from overly restrictive terms in the contracts with service operators? Dr. Chantal Mak then examines European contract law from a different perspective- the perspective of fundamental rights. She thereby addresses an important point of criticism of the consumer law approach: access to and use of digital information products and services touches upon a number of fundamental rights of consumers', notably the right to freedom of expression, privacy and non-discrimination, and of providers, such as the right to property and contractual freedom. If European contract law only accommodates economic, self-centred

\footnotetext{
${ }^{8}$ Directive $2000 / 31 /$ EC of the European Parliament and of the Council of 8 June 2000 on certain legal aspects of information society services, in particular electronic commerce, in the Internal Market ('ECommerce Directive'), OJ L 178/1 (17.07.2000).

${ }^{9}$ Directive 2002/22/EC of the European Parliament and of the Council of 7 March 2002 on universal service and users' rights relating to electronic communications networks and services ('Universal Service Directive'), OJ L 108/51 (24.04.2002).

${ }^{10}$ Directive 2007/65/EC of the European Parliament and of the Council of 11 December 2007 amending Council Directive 89/552/EEC on the coordination of certain provisions laid down by law, regulation or administrative action in Member States concerning the pursuit of television broadcasting activities ('Audiovisual Media Service Directive'), OJ L 332/27 (18.12.2007).

${ }^{11}$ Examples are information about the playability of digital files on consumer devices, the compatibility between certain files and devices, the ability to make copies.
} 
rights and interests of consumers and not more abstract and non-economic rights, such as freedom of expression and privacy, it is, indeed, of only limited use for the digital consumers. Mak investigates how fundamental rights can affect the choices lawmakers and courts make in consumer law. Professor Peter Rott further zooms in on the very specific concerns of the iConsumer. After having concluded that European contract law is only limited helpful to safeguard the interests of the iConsumer, he describes a number of more recent initiatives at the European level to respond to the concerns of the digital consumer. Rott's contributions ends with some suggestions for sector-specific iConsumer contract law, arguing thereby that consumer law, not copyright law is the right place to accommodate the interests of the iConsumer.

A somewhat different approach is taken by Professor Jane Winn and Nicolas Jondet. These authors remind us that solutions to problems in information markets are not necessarily best or alone addressed by law. They discuss the important role that technical standardization plays in consumer protection. Standardization with the ultimate goal to improve interoperability for consumers is of particular relevancy to the iConsumer. Due to the use of a range of conflicting content protection technologies, such as Digital Rights Management (DRM) and Technical Protection Measures (TPM) in information markets, the ability of iConsumers to access and use digital content can be seriously hampered (BEUC 2005). The lack of adequate interoperability solutions also favours lock-in situations that can have a negative effect on choice and competition. Interestingly, France was the first country in the European Union to adopt a solution that is specifically geared towards interoperability problems with DRM solutions and TPM for the protection of copyrights. In their article, Winn and Jondet discuss the French approach critically and point to some flaws and lessons to learn.

Professor Peter Swire, finally, points to an important potential limitation of the consumer law approach: Under which conditions are iConsumers still 'consumers'? Digital technologies did not only trigger new business models and opportunities of marketing digital content to consumers. Digital technologies also empowered users to take on functions that so far were reserved to professional suppliers. The active user or 'prosumer' ${ }^{12}$ is another facet of the iConsumer (Pascu 2008; Wells 2008, pp. 3-5) and one that is potentially at odds with traditional systems of consumer protection (Zarski 2008, pp. 760-764). Accommodating the interests of the iConsumer, both as 'consumer' and as active participant in the production chain is another important challenge of future iConsumer law.

Earlier versions of some of the papers in this JCP special issue were presented at an international workshop that was held on 14-15 December 2007 in Amsterdam. The workshop was organized jointly by the Institute for Information Law, University of Amsterdam (IViR) and the Berkeley Centre for Law and Technology, University of California (BCLT). In this context, the author would like to thank especially Professor Pamela Samuelson (BCLT) and Professor Bernt Hugenholtz (IViR) for co-organizing the event. Thanks are due also to the participants of the workshop. The organizers of the workshop are grateful for the financial support provided by Microsoft Corp. The workshop emphasized, once more, the value and need for a transatlantic dialogue on iConsumer issues. A brief report of the discussions at this workshop can be found at the end of this Special Issue of this journal.

${ }^{12}$ A combination of the words "professional" and "consumer". The term was coined by Alvin Toffler in his book "The Third Wave," Toffler (1980). 
Open Access This article is distributed under the terms of the Creative Commons Attribution Noncommercial License which permits any noncommercial use, distribution, and reproduction in any medium, provided the original author(s) and source are credited.

\section{References}

Benkler, Y. (2000). From consumers to users: shifting the deeper structures of regulation toward sustainable commons and user access. Federal Communications Law Journal, 52, 561-579. Online available at: http://www.law.indiana.edu/fclj/pubs/v52/no3/benkler1.pdf.

BEUC (2005). Test on interoperability between online music stores and portable players. Brussels: The European Consumers' Organisation. Online available at: http:/www.consumersdigitalrights.org/cms/ test interop en.php.

CEC (2007a). Green Paper on the review of the consumer acquis. Brussels: Commission of the European Communities. COM(2006)744 final.

CEC (2007b). Report on the outcome of the public consultation on the green paper on the review of the consumer acquis. Brussels: Commission of the European Communities. Online available at http://ec. europa.eu/consumers/cons_int/safe_shop/acquis/acquis working doc.pdf.

CEC (2008). Green paper on copyright in the knowledge economy. Brussels: Commission of the European Communities. COM(2008) 466/3.

Cohen, J. (2005). The place of the user in copyright law. Fordham Law Review, 74, 347-374. Online available at SSRN: http://ssrn.com/abstract=814664.

Elkin-Koren, N. (2007). Making room for consumers under the DMCA. Berkeley Technology Law Journal, 22, 1119-1155. Online available at SSRN: http://papers.ssrn.com/sol3/papers.cfm?abstract_id=1024566.

EP (2007). Report on consumer confidence in the digital environment. Strasbourg: European Parliament, Committee on the Internal Market and Consumer Protection. A6-0191/207.

EP (2008). European Parliament legislative resolution of 24 September 2008 on the proposal for a directive of the European Parliament and of the Council amending Directive 2002/22/EC on universal service and users' rights relating to electronic communications networks, Directive 2002/58/EC concerning the processing of personal data and the protection of privacy in electronic communications sector and Regulation (EC) No 2006/2004 on consumer protection cooperation. Strasbourg: European Parliament. A6-0318/2008.

Helberger, N., \& Hugenholtz, P. B. (2007). No place like home for making a copy: private copying in European copyright law and consumer law. Berkeley Technology Journal, 22, 1061-1098. Online available at SSRN: http://papers.ssrn.com/sol3/papers.cfm?abstract_id=1012305.

Helberger, N., Dufft, N. S., Kerényi, K., Lambers, R., Orwat, C., Riehm, U., et al. (2004). Digital rights management and consumer acceptability: A multi-disciplinary discussion of consumer concerns and expectations. Amsterdam: Informed Dialogue About Consumer Acceptance of DRM Solutions in Europe. State-of-the-Art Report. Online available at: http://www.indicare.org/tiki-page.php?pageNa me=Downloads.

INDICARE (2006). Consumers' guide to digital rights management. Amsterdam: Informed Dialogue About Consumer Acceptance of DRM Solutions in Europe. Online available at: http://www.indicare.org/tikipage.php?pageName=ConsumerGuide.

Kroes, N. (2008). Making online commerce a reality. Closing remarks at Online Commerce Roundtable. Brussels: Commission of the European Communities. SPEECH/08/437.

Liu, J. P. (2003). copyright law's theory of the consumer. Boston College Law Review, 44, 397-431. Online available at SSRN: http://ssrn.com/abstract=466420.

Mulligan, D. K., \& Perzanowski, A. K. (2007). The magnificence of the disaster: reconstructing the Sony BMG Rootkit Incident. Berkeley Technology Law Journal, 22, 1157-1232. Online available at SSRN: http://papers.ssrn.com/sol3/papers.cfm?abstract_id=1072229.

Pascu, C. (2008). Innovations in communications: The role of users, industry, and policy. Paper presented at the EuroCPR conference, Seville, 31st March-1st April 2008.

Samuelson, P., \& Schultz, J. (2007). Should copyright owners have to give notice about their use of technical protection measures? Journal on Telecommunications and High Technology Law, 11, 41-75. Online available at SSRN: http://ssrn.com/abstract=1058561.

Toffler, A. (1980). The third wave. New York: Morrow. 
Wells, A. (2008). A portrait of early internet adopters: Why people first went online-And why they stayed. Washington: Pew Internet \& American Life Project. Online available at: http://www.pewinternet.org/ pdfs/PIP Early Adopters.pdf.

Wilhelmson, T. (1998). Consumer law and the environment: From consumer to citizen. Journal of Consumer Policy, 21, 45-70.

Zarsky, T. (2008). Law and online social networks: Mapping the challenges and promises of user-generated information flows. Fordham Intellectual Property, Media and Entertainment Law Journal, 18, 741-783. Online available at SSRN: http://papers.ssrn.com/sol3/papers.cfm?abstract_id=1098036. 